\title{
易焼結性および難焼結性 $\mathrm{Al}_{2} \mathrm{O}_{3}$ 粉体の焼結挙動*
}

$$
\begin{aligned}
& \text { 池上隆 沗**, 垣 尾 奉 彦*** } \\
& \text { 千田幸 雄****, 守 吉 佑 介** }
\end{aligned}
$$

Takayasu Ikegami, Hisahiko Kakio, Yukio Chida and Yusuke Moriyoshi: Sintering Behavior of Sinterable and Nonsinterable $\mathrm{Al}_{2} \mathrm{O}_{3}$ Powders.

An alum-derived $\mathrm{Al}_{2} \mathrm{O}_{3}$ powder and aluminum hydroxide one were calcined at $1280^{\circ} \mathrm{C}$ for $2 \mathrm{~h}$ in flowing $\mathrm{O}_{2}$. Both the resultant powders had similar primary particles in size $(\approx 0.2 \mu \mathrm{m})$. The latter had smaller aggregates $(<3 \mu \mathrm{m})$ than the former $(<5 \mu \mathrm{m})$, but was nonsinterable. This nonsinterable behavior was explained from the hard aggregates and from the appreciable contribution of the surface diffusion of atoms toward the sintering of this powder. The porous aggregates of the alum-derived $\mathrm{Al}_{2} \mathrm{O}_{3}$ powder, having randomly arranged primary particles, that is, very dispersed pore sizes were easily disintegrated not only by ball-milling but also by pressing at $200 \mathrm{MPa}$, and the narrow dispersion of small pores $(0.05-0.073 \mu \mathrm{m})$ in the green compact was considered to be one of origins for the sinterable behavior of this powder.

(Received July 15, 1983)

\section{1 緒 言}

高品質の焼結体を得るため，又，省エネルギーのため にできるだけ低い温度で粒成長を㧕制しつつ，充分に緻 密化できる易焼結性粉体の調製はきわめて重要である. 粉体の焼結性が構造敏感 で，その母塩の種類や製造条 件 ${ }^{2 〉}$ によって著しく变化するこよは, 㮸来のあのよりさ らに焼結性の優れた粉体が調製できるとと事を示唆する。 しかしながら，粉体の焼結性は多くの因子”行よって， しか屯複雑に变化するので，個々の因子と焼結性之の関 係を解明するととは難しく，易焼結性粉体は偶然に得ら れることが多かった。

このように複䧴な現象を解明するには，宗ず影響力の 大きい因子から評価していくことが效果的であるう。本 研究は，典型的な易燒結性拉上び難焼結性粉体の燒結挙 動の比較から，重要亡考えられる因子を見出し，それら と軏結性との関係を明らかにするために行った。

\section{1実 験 方 法}

易㶹結性 $\alpha-\mathrm{Al}_{2} \mathrm{O}_{3}$ 粉体 (S) は明ばん由来の $\gamma-\mathrm{Al}_{2} \mathrm{O}_{3}$ (純度 $99.99 \%$ の信光社製) を空気中, $1280^{\circ} \mathrm{C}$ で 2 時間 仮烓して得た。一方，難焼結性粉体 $(\mathrm{H})$ は電孤放電法 によって得た純度 $99.9 \%$ 水酸化アルミニウム（岩谷産 業製）を同じ条件で仮焼したものである。とれらの粉体 の一部は蒸留水でスラリー化した後, 樹脂製のボールミ

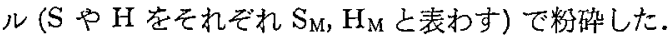

残りはアルミナ乳釚ではぐす程度に俥くすり潰した。と れらの粉体を超硬合金製の金型で直径 $12 \mathrm{~mm}$ ，厚さ約 3 $\mathrm{mm}$ の錠剤状に成形した後, $200 \mathrm{MPa}$ で静水圧成形し た. その後, W 製ヒーターの電気炉を用いて，10-5 torr の真空寄网気， $10^{\circ} \mathrm{C} / \mathrm{min}$ の速度で所定の温度まで暑温 し，その温度にI〜2 㭙間保持した後炡電源を切り炻冷 した．水銀圧入法で気孔径を測定するため，焼結体を砕 き，150 270 mesh に穊分けた．又，軽く砕いた焼結体 の破断面の SEM 写真加ら，一次粒子や 2 次粒子の大 きさ，凝集粒子の形態を調べた，粒子の大きさは，SEM 写真上の粒子の面積を円の面積で近似して，その円の直 径で表わした。

\section{III 実験結果亡考察}

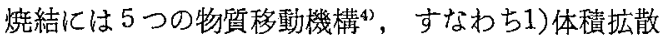
2)粒界搪散，3）粘性又は塑性流動，4)表面拡散および5) 蒸発一凝固の各機構が報告されている。酸化物系セラミ ックス ${ }^{5}$ では，一般に1)や2)が支配的であると考えられ ているが，燒結温度")ばかりでなく粉体の製造条件てに

* 第21回窵業基礎討論会にて発表，昭和58年 7 月 15 日受理.

** 烸機村質研究所， 干305 药城県新治郡桜村並木一丁目一 㧞地

****多木化学(株)， テ675-01 兵庫県加古川市別狩町緑町二番 地

**** 三菱化成工業(株)炭素無機研究所， 于227 横浜书緑区鴨 志田町 4 番地 
Table 1 Results of the emission spectrochemical analysis of alum-derived (S-) and hydroxide-derived ( $\left.\mathrm{H}_{-}\right) \mathrm{Al}_{2} \mathrm{O}_{3}$ powders.

\begin{tabular}{|c|c|c|c|c|c|c|c|c|c|}
\hline \multirow{2}{*}{ Sample } & \multicolumn{9}{|c|}{ Impurities (\%) } \\
\hline & $\mathrm{Ca}$ & $\mathrm{Cu}$ & $\mathrm{Fe}$ & $\mathrm{Ga}$ & $\mathrm{Mg}$ & Mn & $\mathrm{Ni}$ & $\mathrm{Pb}$ & $\mathrm{Si}$ \\
\hline $\mathrm{S}-\mathrm{Al}_{2} \mathrm{O}_{3}$ & $0.00 \mathrm{~N}$ & & $0.00 \mathrm{~N}$ & $0.00 \mathrm{~N}$ & $0.00 \mathrm{~N}$ & $0.00 \mathrm{~N}$ & $0.00 \mathrm{~N}$ & $0.00 \mathrm{~N}$ & $0.00 \mathrm{~N}$ \\
\hline $\mathrm{H}-\mathrm{Al}_{2} \mathrm{O}_{3}$ & $0.00 \mathrm{~N}$ & $0.00 \mathrm{~N}$ & $\begin{array}{l}0.0 \mathrm{~N}- \\
0.00 \mathrm{~N}\end{array}$ & $\begin{array}{l}0.0 \mathrm{~N}- \\
0.00 \mathrm{~N}\end{array}$ & $0.00 \mathrm{~N}$ & $0.00 \mathrm{~N}$ & $0.00 \mathrm{~N}$ & $0.00 \mathrm{~N}$ & $0.00 \mathrm{~N}$ \\
\hline
\end{tabular}
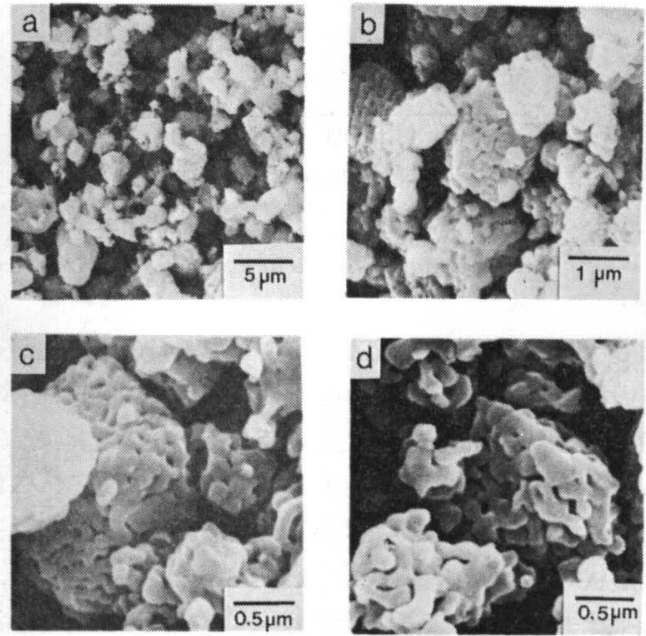

Photo. 1 SEM images of hydroxide-derived $\mathrm{Al}_{2} \mathrm{O}_{3}$ powders. a and b- $\mathrm{H}-\mathrm{Al}_{2} \mathrm{O}_{3}, \mathrm{c}-\mathrm{H}-\mathrm{Al}_{2} \mathrm{O}_{3}$ pressed at $200 \mathrm{MPa}$ and c- $\mathrm{H}-\mathrm{Al}_{2} \mathrm{O}_{3}$ ball-milled $\left(\mathrm{H}_{\mathrm{M}}-\mathrm{Al}_{2} \mathrm{O}_{3}\right)$.

よってあ支配的な物質移動機構が変わるととあある.焼 結機構が異なる場合に焼結性を比較するととは, 性質が 異なるものを比較するととになるので学問的には意味が ない.しかし，実用的要請から種々の条件で調製した粉 体の焼結性を比較する必要があるときは, 機構を無視し て, 単に圧粉体の収縮速度 ${ }^{8)}$ や到達密度 ${ }^{9}$ で評価するこ とが多い。ここで述べる焼結性もこれらの基準で判断し た.

\section{III-1 粉体の性質}

未粉砕粉体の発光分析の結果を Table 1 に示した. この Table から分かるように, Fe や Ga 以外の不純物 には特に差異を認められなかった。

SEM によるH系の観察結果を Photo. 1 に示した. 比較的倍率の低い Photo. 1(a) 㘦分かるように, Hの 粒径は 1 3 $3 \mu \mathrm{m}$ と良く揃っている. 倍率を上げて観察 (b) すると, それらは約 $0.2 \mu \mathrm{m}$ の一次粒子が単純立方 に近い配列で凝集したあのであるととが分かる.X線の 回折ピークには $\alpha$ 相のピークに相当するものしか認め られず, 又, 各ピークの幅は結晶子の大きさが正確に計 算できない程に狭（粒径が約 $0.15 \mu \mathrm{m}$ 以上）かったの で, 上で述べた一次粒子は $\alpha-\mathrm{Al}_{2} \mathrm{O}_{3}$ の結晶子に相当す ると考えられる. Photo. 1(b) から測定した一次粒子間の
気孔径は $0.05 \sim 0.09 \mu \mathrm{m}$ の間にあり, 平均気孔径は約 $0.075 \mu \mathrm{m}$ であった. 一次粒子間の接合は, ネックの直 径が一次粒子の直径の約 $60 \%$ になるまで進んでいた。凝 集粒子は強固で, SEM 写真では明らかに成形 (c) や粒 砕 (d) によって崩解したと分かるような凝集粒子を見出 すととはできなかった，千田ら ${ }^{103}$ は市販の水酸化物を $1250^{\circ} \mathrm{C}$ で仮焼して得た $\alpha-\mathrm{Al}_{2} \mathrm{O}_{3}$ 粉体の生高密度と 6 $\mathrm{GPa}$ までの圧粉圧の関係を調へ， 乙の凝集粒子が細か く崩壊する圧粉圧を $900 \mathrm{MPa}$ と見積っている．Hは電 孤放電法という特殊な方法で調製した水酸化物を仮焼し て得た $\alpha-\mathrm{Al}_{2} \mathrm{O}_{3}$ であるので, 千田らの用いた粉体とは 異なる圧力依存性を示すかむしれない，しかしながら， 一次粒子の大きさや配列, 一次粒子間の接合の程度など が千田らの用いた粉体とほぼ同じであるととは，Hの凝 集粒子を細汃く崩壊させる場合も $900 \mathrm{MPa}$ 程度の相当 高い压粉圧が必要であることを示唆している.

てれに対し，Sは Photo. 2(e) に示したように，0.5〜 $5 \mu \mathrm{m}$ と $\mathrm{H}$ に比べ非常に広い粒度分布を持っていた. 各粒子は約 $0.2 \mu \mathrm{m}$ の結晶子 ( $\mathrm{H}$ と同様な理由で判断し た）が凝集 (f) したもので, 結晶子間の気孔径の分布は $0.07 \sim 0.8 \mu \mathrm{m}$ と広加た. 凝集粒子は脆弱で粉碎 (h) ばかりでなく, 成形 $(\mathrm{g})$ によっても比較的容易に壊すて
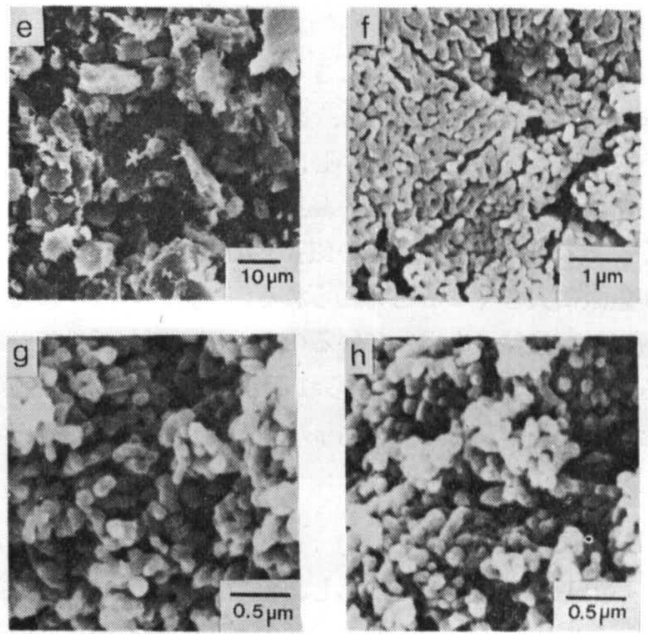

Photo. 2 SEM images of alum-derived $\mathrm{Al}_{2} \mathrm{O}_{3}$ powders. a and b-S- $\mathrm{Al}_{2} \mathrm{O}_{3}, \mathrm{c}-\mathrm{S}-\mathrm{Al}_{2} \mathrm{O}_{3}$ pressed at $200 \mathrm{MPa}$ and c-S- $\mathrm{Al}_{2} \mathrm{O}_{3}$ ball-milled $\left(\mathrm{S}_{\mathrm{M}}-\mathrm{Al}_{2} \mathrm{O}_{3}\right)$. 
Table 2 The diameter and density of S- and $\mathrm{H}-\mathrm{Al}_{2} \mathrm{O}_{3}$ compacts formed at various pressures.

\begin{tabular}{|c|c|c|c|c|}
\hline \multirow{2}{*}{$\begin{array}{l}\text { Pressure } \\
\left(\mathrm{kg} / \mathrm{cm}^{2}\right)\end{array}$} & \multicolumn{2}{|c|}{$\mathrm{S}-\mathrm{Al}_{2} \mathrm{O}_{3}$} & \multicolumn{2}{|c|}{$\mathrm{H}-\mathrm{Al}_{2} \mathrm{O}_{3}$} \\
\hline & $\begin{array}{l}\text { diameter } \\
(\mathrm{mm})\end{array}$ & $\begin{array}{c}\text { density } \\
(96)\end{array}$ & $\begin{array}{l}\text { diameter } \\
(\mathrm{mm})\end{array}$ & $\begin{array}{c}\text { density } \\
(\%)\end{array}$ \\
\hline 350 & 7.47 & 32 & 7.68 & 37 \\
\hline 1000 & 6.90 & 39 & 7. 45 & 40 \\
\hline 2000 & 6.67 & 45 & 7.38 & 44 \\
\hline
\end{tabular}

とができた，この脆い理由の1つとして，凝集粒子内に ある大きい気孔の存在が考えられる。向し，単位面皘当 りの接合面の強さや一次粒子の大きさが同じで， 0.075 $\mu \mathrm{m}$ の気孔の近傍にある接合面が $900 \mathrm{MPa}$ で破断する 之仮定すると, $200 \mathrm{MPa}$ の圧粉圧は $0.2 \mu \mathrm{m}$ の気孔の近 傍にある接合面を破断できることになる。記の仅定注 問題を非常に単純化しており, 又, 計算屯大変粗いので, $\mathrm{S}$ の凝集粒子内の $0.2 \mu \mathrm{m}$ の径を持つ気孔の近傍にある 接合面が $200 \mathrm{MPa}$ の压粉压で切断すると結論づけるこ とはできない，しかしながら，接合面に俉く実効応力は， 接合面の面積よりも気孔の断面皘の方が大きくなると， 気孔径が大きくなるに従い急激に大きくなるので，一次 粒子の直径の 4 倍むある $(0.07 \sim 0.8 \mu \mathrm{m})$ 大きい気孔を 持つ $\mathrm{S}$ の凝集粒子は大変脆弱なはずで, $200 \mathrm{MPa}$ 以下 の住粉圧であある程度壊わすととができるととは確かで あるう。

\section{III-2 圧粉压亡允てん密度の関保}

内径が $8 \phi$ の超硬合金製の金型を用い，非常に低い圧 力 (10 ton プレスの針がわずかに振れる程度) で 1 次成 形した後, 所定の圧で静水圧プレスした压粉体の直径D とその密度 $\rho_{0}$ を測定した．との結果を示した Table 2 加分加るように，SのDは $7.47 \mathrm{~mm}$ 加ら $6.57 \mathrm{~mm}$, $\rho_{0}$ としては $32 \%$ から $45 \%$ まで変化する.一方, H の D は $7.68 \mathrm{~mm}$ から $7.28 \mathrm{~mm}, \rho_{0}$ は $37 \%$ から $44 \%$ まで変 化したに過ぎない.とれらの結果はすでに述べたように， 凝集粒子の性質から説明できる. 王粉圧が非常に低いと きにSの $\rho_{0}$ が小さいのは，凝集䊒子の見圤上の密度が 小さいためであろう。しかし，ての凝集粒子は脆いので， 压粉圧が高くなると壊れ，凝集粒子間の気孔ばかりでな く，その中の比較的大きい気孔消失し，その結果， $\rho_{0}$ が急激に大きくなると考えられる。一方，HはSに比べ 緻密な凝集粓子を持っているので，压粉圧が低くてああ る程度大きい $\rho_{0}$ の值が得られるが，凝集粒子が強固な ため压粉圧が高くなってあ 0 はあますり增加しないと考 えられる。

\section{III-3 圧粉体の焼結}

Fig. 1 は各温度まで加熱し，その温度で 1 時間保持し た $\mathrm{S}_{\mathrm{M}}$ および $\mathrm{H}, \mathrm{H}_{\mathrm{M}}$ の焼結体の到達密度を示している. S は焼結温度が $1400^{\circ} \mathrm{C}$ であ, 相対密度は92\%まで上 がるが， $\mathrm{H}$ や $\mathrm{H}_{\mathrm{M}}$ は同じ焼結温度では52〜 58\%，1600 $\mathrm{C}$

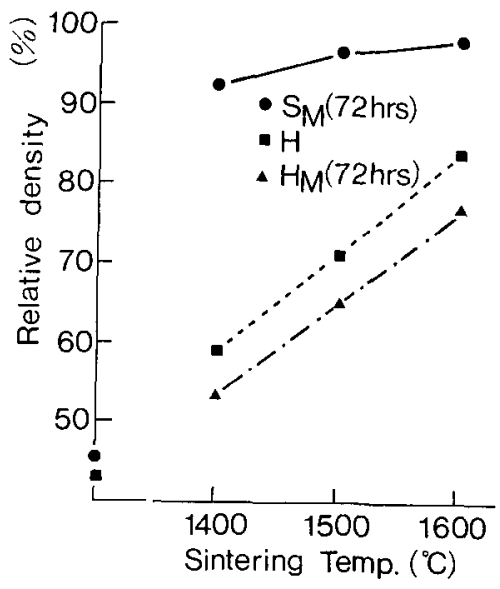

Fig. 1 The density of a compact sintered at given temperatures for $2 \mathrm{~h}$ in vacuum.

でも75〜85\%以上には上がらなかった．Hの焼結性が劣 るのは，压粉体の成形性加ら分加るように，凝集粒子の 強度に原因があると考えられる。との粉体で興味があ る事は，粉碎により焼結性が劣化することである。これ は粉砕過程で，㙥れる凝集粒子ばかりでなく，凝集粒子 の形状が変ったり，凝集粒子どうしが圧着したりして， 凝集粒子の充てんの均一性が悪くなったためと考えられ る. S の場合, Table 3 加分加るように緻密化を促進 させるのに粉砕が大变効果的である，粉砕により焼結密 度ばかりでなく $\rho_{0}$ あ上がることは，乙の処理により凝 集粒子が壊れ，粒子の充てんの均一性が良くなること， さらに凝集粒子をは㜔完全に壊すためには，200 MPa の 圧粉压では不充分であるととを示唆している。

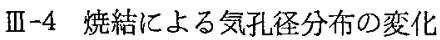

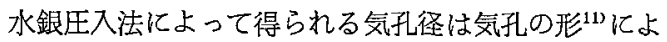
っても変わる，さらに，压粉体や焼結体の上うに“inkbottle” 型の気孔 ${ }^{12}$ を持つ試料では，入口の小さな気孔 の大きさを測定し，それに続くより大きい気孔の大きさ を評価することはできないので，得られたデータを解析 するときには注意が必要である. ink·bottle 型の気孔の 影響を小さくするには焼結体を小さく础くことが望まし いが，小さすぎると粉确柆子間にできる空腙径の分布と 測定しようとする気孔径分布とが重なる恐れがある. 予 備的実験を行った所, 270 mesh 以下の粒子を用いると重

Table 3 The effects of ball-milling on the green and sintered densities (96) of $\mathrm{S}-\mathrm{Al}_{2} \mathrm{O}_{3}$ powders.

\begin{tabular}{lccc}
\hline \multirow{2}{*}{ Sample } & \multicolumn{3}{c}{ Ball-milling time $(\mathrm{h})$} \\
\cline { 2 - 4 } & 0 & 24 & 72 \\
\hline green & 42 & 45 & 46 \\
sintered & 79 & 89 & 92 \\
\hline
\end{tabular}




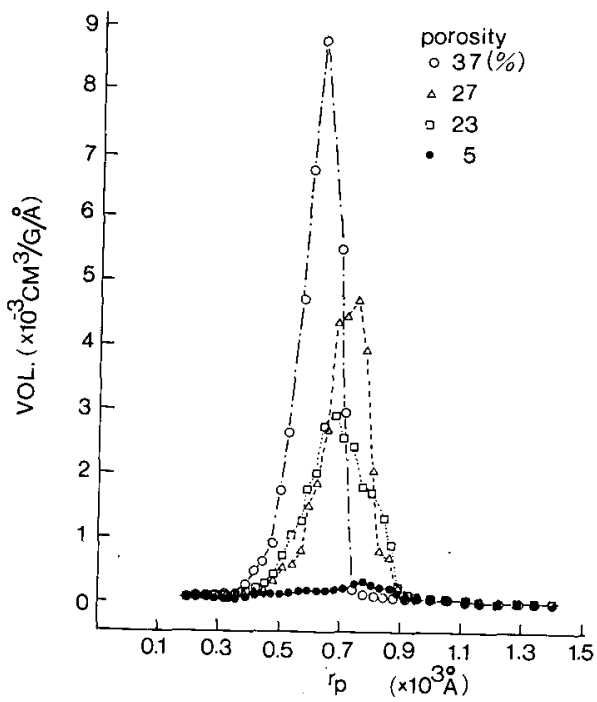

Fig. 2 The change of the pore size distribution of $\mathrm{S}_{-} \mathrm{Al}_{2} \mathrm{O}_{3}$ was sintered to given various temperatures at a heating rate of $10^{\circ} \mathrm{C} / \mathrm{min}$ in vacuum. The sample with porosity $\mathrm{P}=37 \%$ was heated at $1300^{\circ} \mathrm{C}$ for 1 $\mathrm{h}$, with $\mathrm{P}=27 \not 6$ at $1400^{\circ} \mathrm{C}$ for $1 \mathrm{~h}$, with $23 \not 6$ at $1400^{\circ} \mathrm{C}$ for $2 \mathrm{~h}$ and with $\mathrm{P}=5 \%$ at $1600^{\circ} \mathrm{C}$ for $1 \mathrm{~h}$, respectively. The ordinate in this figure shows a pore volume per a unit weight in the range between grain size $r_{p}$ and $r_{p}+30 \AA$.

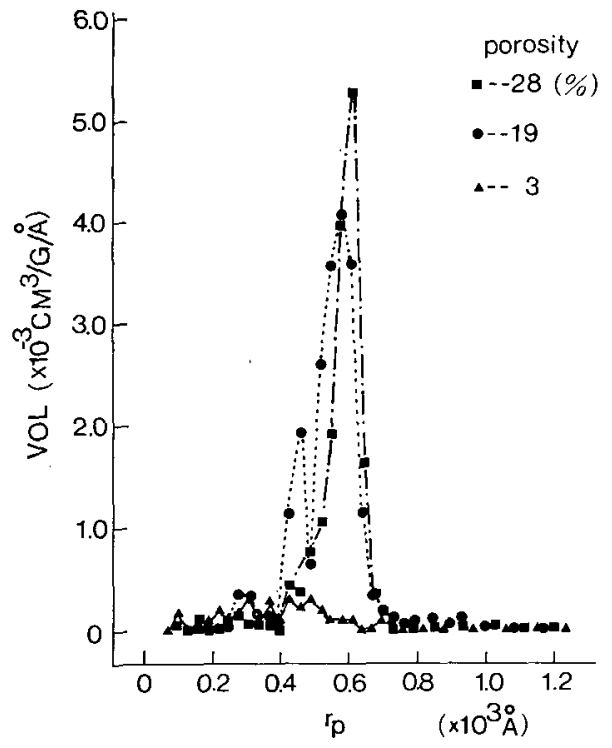

Fig. 3 The change of the pore size distribution of $\mathrm{S}_{\mathrm{M}}$ $\mathrm{Al}_{2} \mathrm{O}_{3}$ was sintered to given various temperatures at a heating rate of $10^{\circ} \mathrm{C} / \mathrm{min}$. in vacuum. The sample with $\mathrm{P}=2896$ was heated at $1250^{\circ} \mathrm{C}$, with $\mathrm{P}=19 \%$ at $1400^{\circ} \mathrm{C}$ and with $\mathrm{P}=3 \%$ at $1500^{\circ} \mathrm{C}$ for $1 \mathrm{~h}$, res. pectively.
なることが分かったので，本研究では 150～270 mesh 間 の粒子を测定した。

$\mathrm{S}$ 上 $\mathrm{S}_{\mathrm{M}}$ の㜔結過程における気孔湰分布の变化を，を れぞれ Fig. 2 と 3 に示した.これらの図に示された気 孔径分布は $0.06 \mu$ の所にピークがある比較的狭小分布 で特徽づけることができる. Fig. 3 から分かるように， $S_{M}$ の気孔径分布の山の高さは維密化が進むにつれ低く なり，その位置は気孔径が小さくなる方へ変った。この 変化は緻密化か焼結体の場所によらず比較的均等に進ん でいることを示唆している．これに対し，Sの気孔径分 布は維密化が $\rho=0.63$ 加ら0.73八進む過程では, 気孔 径が大きくなる方へ変化した，焼結中に大きくなる気孔 ああるということは，焼結体内の微細領域によっては㜔 結体のマクロ的な变化とは逆な現象が起こっていること を意味している．このような複雑な現象が起こる理由の 1 つとして，粒子の不均一な充てんが考えられる. Fig.4 はこの事をモデル的に示したものである．粒子の充てん が不均一であると，維密化の際に各粒子に作用する相互 作用の大きさは，粒子の周囲の情況によって変わるはず である. 密に充てんした領域の粒子に働く相互作用は, 粒子間の接触点が多いだけに強いと考えられる。これに 対し，充てんが蹯であるとそれだけ相互作用む弱く，充 てんが疎な所の繏密化は密充てんした所の焼結挙動によ って左右され，密充てんした所で進む縹密化の情況によ っては，気孔が成長する所 (失印) むありうると考えら れる. これに対し， $\rho=0.73$ から0.95までの間で気孔の 成長があまりみられないのは，粒子の再配列が $\rho=0.73$ までにほぼ終るためであろう。気孔の成長は Ostwaldripening ${ }^{13)}$ や表面㹡散 ${ }^{14)}$, 蒸発-凝固 ${ }^{4}$ 亿上る物質移動 であ説明できるが, $\rho$ が 0.73 以上で気孔の成長がほとん ど止まる現象をこれらの物質移動で説明するととはでき ない.

Fig. 5 と6に示したように， $\mathrm{H}$ 系粉の焼結体の気孔径 分布は粉砕姏理を施したものあ，また施さなかったもの 62つの山を持つ広い分布を示している. 高い力のピー クの位直は約 $0.15 \sim 0.18 \mu \mathrm{m}$ で 2 次粒子の約 $1 / 5$ ，また 低いピークの位置は 0.06〜0.08 $\mu \mathrm{m}$ で一次粒子の約 $2 / 5$ であった．したがって高い方のピークは凝集粒子間の気 孔颈分布を表わし，また低い力は凝集粒子の内部の気孔 径分布定表わしていると考えられる。凝集粒子間の気孔 径に対する凝集粒子径の比が，一次粒子間の気孔径に対

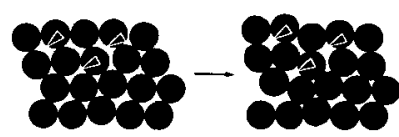

Fig. 4 A schematic model of particles rearrangement during sintering. Arrows indicate pores that grow with densification of microregions with relatively high density. 


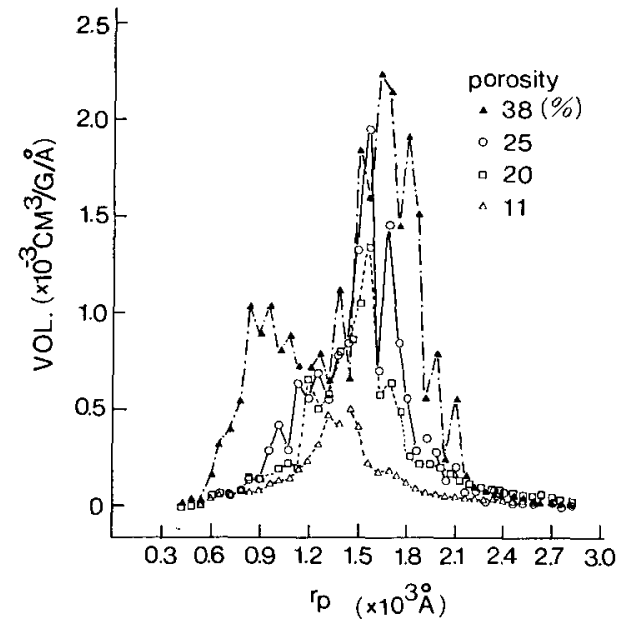

Fig. 5 The change of the pore size distribution of $\mathrm{H}-\mathrm{Al}_{2} \mathrm{O}_{3}$ was sintered to given various temperatures at a heating rate of $10^{\circ} \mathrm{C} / \mathrm{min}$, in vacuum. The sample with $\mathrm{P}=38 \% 6$ was heated at $1400^{\circ} \mathrm{C}$ for $1 \mathrm{~h}$, with $\mathrm{P}$ $=25,6$ at $1500^{\circ} \mathrm{C}$ for $0.8 \mathrm{~h}$, with $\mathrm{P}=20,6$ at $1500^{\circ} \mathrm{C}$ for $2 \mathrm{~h}$ and with $\mathrm{P}=11,8$ at $1600^{\circ} \mathrm{C}$ for $2 \mathrm{~h}$, respectively.

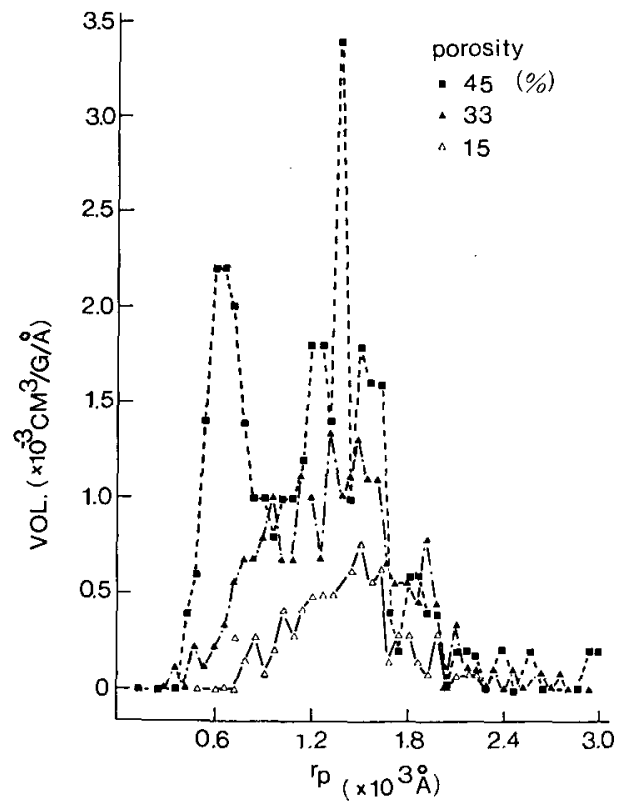

Fig. 6 The change of the pore size distribution of $\mathrm{H}_{\mathrm{M}}$. $\mathrm{Al}_{2} \mathrm{O}_{3}$ was sintered to give various temperatures at a heating rate of $10^{\circ} \mathrm{C} / \mathrm{min}$. in vacuum. The sample with $\mathrm{P}=45$ go was heated at $1400^{\circ} \mathrm{C}$ for $1 \mathrm{~h}$, with $\mathrm{P}$ $=33 \%$ at $1500^{\circ} \mathrm{C}$ for $0.8 \mathrm{~h}$ and with $\mathrm{P}=15 \%$ at $1600^{\circ} \mathrm{C}$ for $2 \mathrm{~h}$, respectively.
する一次粒子径の比に比較して小さいのは，凝集粒子径 の分布が一次精子径の分布に比へて広いことから示唆さ れるように，大きい凝集粒子の間に小さい粒子が入って いるためであるう。実用的な要請により，成形体の密度 を上げるために，種々の大きさの粒子を配合 ${ }^{15}$ すること は良く行われている。一方，山が低い方の気孔径分布の 烧結過程における変化は，径の小さい気孔が優先的に消 失することで特徽づけることができる. Photo. 1(b)〜(d) 加ら分加るように，てれらの一次粒子注単純立方近い 比較的, 規則的な配列をしているので，小さな気孔が優 先的に消失する理由をすでに述べた不均一な収縮で説明 することは難しいすすなわち，Ostwald-ripening ${ }^{133}$ や表 面抆散 ${ }^{(4)}$ ，蒸発一凝固 ${ }^{4}$ による気孔成長で説明するのが 妥当であろう. Ostwald-ripening による気孔成長が支配 的であると，気孔の消長はあるが，それらの位置は固定 されているので，粒成長が同時に進行すると気孔は粒内 に取込れるはずである．開放気孔の気孔率と相対密度の 和が 1 亿等しいので，乙の物質移動は支配的でない之考 えられる. 又, 圧粉体之焼結体の重量差（約 1\%）加真 空狫結の温度によって変化しないてとは，高温における 試料の蒸発, すなわち, 蒸発一凝固による粒成長が無視 できることを示唆している，それ故，小さな気孔が優先 的に消失した原因は，難焼結性である水酸化物由来 $\mathrm{BeO}$ の烧結過程の直接観察 ${ }^{142}$ 加ら類推できるよう亿表面搪散 による気孔の成長であると考えられる。

Hのピークが低い気孔䅅分布之高い気孔径分布の燒結 過程で起こる変化を比較すると，ピークが高い方の気孔 径分布では相刘的に大きい気孔が，低い方の気孔分布で は逆に小さい気孔が優先的に消失した，そのため，全体 的な分布の幅は緻密化が進むにつれて狭くなった。てれ に対し $\mathrm{H}_{\mathrm{M}}$ の場合，いずれの気孔径分布屯焼結が進む につれて気孔径が大きくなる方へ移動するため，全体的 な分布の幅はすまり変化しなかった，凝等粒子を基本粒 子とみなして焼結過程代抒りる気孔分布の変化を特徽つ けると，Hの場合，凝集粒子が均一に充てんしたときに 起こる变化に近った。一方, $\mathrm{H}_{\mathrm{M}}$ の場合は凝集粒子の充 てんが悪いときに得られるすのに似ている．粉确処理を 施したために $\mathrm{H}_{M}$ の充てんの均一性が㓦くなった理由 はすでに III-3で，粉碎過程で起こる凝集粒子どうしの王 着や凝集粒子の形状変化で説明した. 特に $\mathrm{H}_{\mathrm{M}}$ の気孔 に $0.24 \sim 0.3 \mu \mathrm{m}$ と大きい気孔ああることは, 压粉圧に 耐える程度に強く圧着した面もあることを示している。

Fig. 7 は相対密度 $\rho$ 之平均粒径 $R$ の関係を $\sigma\left(1-\rho_{0}\right) /$ $\rho_{0}(1-\rho)$ と $R / R_{0}$ の形で点綴したものである. この直線 の傾きから充てん性の度合や，維密化走起てさない物質 移動の寄与屯ある程度評価 ${ }^{16)}$ できる．S の絰密化は粒成 長とと屯に順調に進むが，Hは $R$ が $1.2 \mu \mathrm{m}$ 以上にな らないとあまり進まない，これはすでに述べたように， 


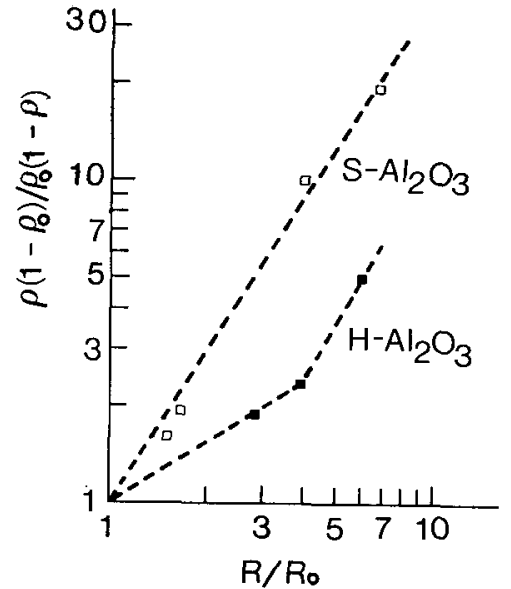

Fig. 7 Relation between density $\rho$ and average radius $R$. $\rho_{0}$ and Roare the initial values of $\rho$ and $R$, respectively. $\mathrm{S}-\mathrm{Al}_{2} \mathrm{O}_{3}$ powdered compacts were sintered at $1300^{\circ} \mathrm{C}$ for $1 \mathrm{~h}$, at $1350^{\circ} \mathrm{C}$ for $1 \mathrm{~h}$, at $1400^{\circ} \mathrm{C}$ for $1.5 \mathrm{~h}$ and $1500^{\circ} \mathrm{C}$ for $1 \mathrm{~h}$, respectively. $\mathrm{H}-\mathrm{Al}_{2} \mathrm{O}_{3}$ powdered compacts were sintered at $1400^{\circ} \mathrm{C}$ for 1.5 $\mathrm{h}$, at $1500^{\circ} \mathrm{C}$ for $1.5 \mathrm{~h}$ and $1600^{\circ} \mathrm{C}$ for $2 \mathrm{~h}$, respectively.

維密化を起とす物質移動ばかりでなく，表面拡散による 物犋移動屯同時化進行しているためと考えられる．直線 の傾きが変わる $R$ の值が凝集粒子の大きさにほぼ等し いととや，気孔の成長が Fig. 5 加分かるように，一 次粒子間の気孔径分有を表わしていると考えられる気孔 径分布領域で起こっていることなどから，表面拡散に上 る物質移動柱主に凝集粒子内で進行していたと考えられ る. 以上の考察から, 明ばん由来および水酸化物由来 $\alpha-\mathrm{Al}_{2} \mathrm{O}_{3}$ の焼結性の差はそ机らの凝集粒子の強さ之, 凝 集粒子内で進行する表面拡散機構による物質移動の寄与 の程度によって説明できる。

\section{$N$ 結 論}

易焼結性である明ばん由来扔よび難燒結性である水酸 化物由来の $\alpha-\mathrm{Al}_{2} \mathrm{O}_{3}$ 粉体について, 凝集粒子の構造, 気孔径分布, 平均粒径等を調べ, それらの焼結挙動を検 討した. その結果以下のような結論が得られた。
1) $\mathrm{Al}_{2} \mathrm{O}_{3}$ の焼結性におよぽす因子として, 従来特に問 題にされていた疑集粒子の強さは，凝集粒子内の気孔の 大きさやその分布，一次粒子間の接合面の広さ等である 程度評価できた。

2) 明ばん由来 $\alpha-\mathrm{Al}_{2} \mathrm{O}_{3}$ の凝集粒子は，比較的大きく， しかもその気孔径分布は幅が広いので，200 MPa の压 粉圧を負荷しても，あとの凝集粒子が判別できないほど 壊れた。この粉体を粉碎すると凝集粒子の破壊はさらに 進み，一次粒子がより均一に充てんした成形体が得られ， 焼結性が良くなる。

3）水酸化物由来 $\alpha-\mathrm{Al}_{2} \mathrm{O}_{3}$ の凝集粒子は強固で，本実 験条件で粉砕処理を施しても，凝集粒子を充分に壊すと とが難しいばかりでなく，凝集粒子の充てん性す鱼くな った。

4) 水酸化物由来 $\alpha \cdot \mathrm{Al}_{2} \mathrm{O}_{3}$ の焼結性は緻密化を進行さ せる物質移動ばかりでなく，その凝集粒子内では表面昖 散による物質移動も無視できないととが分かった。

\section{文献}

1）池上，松田，鈴木：䈍協，81 (1973)，322.

2）加藤，大門，山口，山田：嘿協，85 (1977)，134.

3）橋本，浜野共著：也ラミックスの基礎，共立出版（1975), p. 294.

4) J. G. R. Rockland: Acta Met., 15 (1967), 277.

5) 浅贺，浜野：突協，83 (1975)，136.

6) D. T. Livey and A. W. Hey: J. Nucl. Mat., 14 (1964), 285.

7) M. F. Ashby: Acta Met., 22 (1974), 275.

8) G. P. Halbfinger and M. Kolodney: J. Amer. Ceram. Soc., 55 (1972), 519.

9) R. A. Brown: Amer. Ceram. Soc. Bull., 44 (1965), 693.

10）干田，池上，守吉：第 21 回案業基礎討論会講演要旨集， (1983), 69.

11) R. P. Mayer and R. A. Stowe: J. Colloid Sci, 20 (1965), 893.

12）鈴木：粉体打上び粉末治金, 17 (1970), 155.

13) G. W. Greenwood: Acta Met., 4 (1956), 243.

14) T. Ikegami, S. Matsuda, Y. Moriyoshi and H. Suzuki : J. Amer. Ceram. Soc., 61 (1978), 532.

15）久保，神保，水渡，高橋，早川共編：粉体理論と応用， (1979), 340.

16) T. Ikegami, M. Tsutsumi, S. Matsuda, S. Shirasaki and H. Suzuki : J. Appl. Phys., 49 (1978), 4238. 